\title{
Conceptual Model of Relationship Between Transformational and Passive Leadership, Safety Knowledge, Safety Attitude, Riding Confidence, Risk Perception, and Risky Driving Behavior
}

\author{
Yunata Amjad ${ }^{1, *}$, Novie Susanto ${ }^{1}$, Naniek Utami Handayani ${ }^{1}$
}

\author{
${ }^{1}$ Industrial Engineering Department, Faculty of Engineering, Universitas Diponegoro, Semarang - Indonesia \\ ${ }^{*}$ Corresponding author. Email: yunata.amjad54@gmail.com
}

\begin{abstract}
In 2020 the development of online public transportation in Indonesia increased significantly. There will be 21.7 million registered users in Indonesia. Online motorcycle taxis are public transportation that is in great demand by the public. But besides that, the high number of motorcycle accidents and especially the high number of online motorcycle taxi drivers is a new problem in online motorcycle taxi public transportation security services. Although, the online motorcycle taxi company has collaborated with PT. Sarana Aman Berkendara since 2016 until now, as a facilitator for online motorcycle taxi drivers in conducting driving safety training programs purposed to prioritize the safety and comfort of passengers. But the results according to the Minister of Transportation in 2017, Budi Karya stated that online motorcycle taxis accounted for 58.715 cases of road accidents in 2017. That indicates that online motorcycle taxi drivers engage in unsafe driving behavior. So, this study aims to determine the influence of factors that influence risky driving behavior and the differences in their effects on drivers who have participated in the driver safety program of PT. Sarana Aman Berkendara and those who have not followed the safety program. This study uses several models that have applied to previous studies. Our model consists of 5 variables and 74 indicators. There are ten hypotheses to be tested using the SEM-PLS method. We used 140 respondents as our sample. The results showed that the sample drivers who took part in the program and did not follow the program had the same number. There are four relationship hypotheses rejected. Other than that, it shows that safety knowledge and riding confidence are perceived to play a major role in reducing risky driving behavior. The recommendation for online motorcycle taxi transportation is to increase the influence of transformational leaders so that safety knowledge will be increased and reduce risky driving behavior.
\end{abstract}

Keywords: Safety Riding Program, Transformational \& Passive Leadership, Safety Knowledge, Risky Driving Behavior.

\section{INTRODUCTION}

Transportation is a system consisting of certain facilities along with flow and control systems that allow people to move from one place to another efficiently at any time to support human activities. [1]. In Indonesia, public transportation has become a basic need of society because it can facilitate mobility and accessibility. One of the public transportations in Indonesia is online motorcycle taxis. Online motorcycle taxis are public transportation based on a certain application where customers order transportation facilities through an application system on a smartphone. Online motorcycle taxis are public transportation that is very popular with the public. In 2020 have 21.7 million users registered in Indonesia [2]. Since 2016 PT. Gojek cooperates with PT. Sarana Aman Berkendara to improve driving safety for online motorcycle taxi drivers. PT. Sarana Aman Berkendara plays a role as a facilitator for online motorcycle taxi drivers in conducting a driving safety training program to always prioritize the safety and comfort of the passengers. but in fact, there is a new problem, namely the high rate of accidents on online motorcycle taxis, according to the Minister of Transportation in 2017, Budi Karya said there were $72 \%$ of motorcycle riders experiencing traffic accidents, which is about 130.000 motorcycle riders involved in traffic 
accidents on the highway, of the number of motorcycle accidents on the road, online motorcycle taxi drivers accounted for 58.715 cases of accidents in 2017 [3]. Arman Achdiat also said cases of traffic violations in 2018 online motorcycle taxi drivers had been involved in traffic violations as many as 677 cases and increased in 2019 to 696 cases, with unaccounted data still available [4]. The Indonesian Consumer Institute Foundation researched 4,668 online motorcycle taxi service users and resulted in 221 respondents, $4.61 \%$ complaining about reckless online motorcycle taxi drivers while driving [5]. In a study conducted by Tao Wang et al, it was found that human behavior is the main cause of most accidents on motorbikes. [6].

After knowing the problems, researchers see the need to look at the factors that influence the high rate of accidents on online motorcycle taxi drivers, and by looking at the effect of safety programs on online motorcycle taxi drivers. This study aims to describe the relationship of Transformational \& Passive Leadership, Safety Knowledge, Safety Attitude, Riding Confidence, Risk Perception to Risky Driving Behavior on online motorcycle taxi drivers. This research will be conducted on 2 types of samples for online motorcycle taxi drivers, namely drivers who have studied at PT. Safe Driving Facilities and drivers who have not attended driving safety training.

\section{LITERATURE}

\subsection{Relationship of Variable}

This research uses some previous research to build hypothetical relationships between variables used. The variables are Transformational \& Passive leadership, Safety knowledge, Safety attitude, Risk perception, Riding confidence, and Risky driving behavior.

\subsection{Passive \& Transformational Leadership}

Leader types positively influence organizational and individual outcomes, including organizational commitment [7], employee performance [8], employee satisfaction with leadership [9]. There are two types of leadership in organizations, namely transformational leaders and passive leaders. The type of transformational leader is the type who is concerned with employee welfare and employee safety and is considered the most effective type for the organization in the workplace. Barling, Loughlin, and Kelloway say that perceptions of transformational leadership specifically on worker safety are related to individual safety awareness and perceptions of worker safety climate [7]. Given its positive impact on organizational outcomes, transformational leadership is considered highly effective leadership [9].

\subsection{Safety Knowledge}

Safety knowledge is employee knowledge of safety procedures and safety practices in the workplace. Blattenberger, Fowles, and Loeb summarize from several empirical findings that a better understanding of road rules/traffic rules will create a safer driving environment [10]. Vanlaar et al investigated the relationship between knowledge, attitudes and aggressive driving behavior for motorists in Canada with a total of 1.201 questionnaires collected and the results showed that risky driving behavior could be improved by increasing the knowledge of drivers [11]. Vanlaar et al said that there is a strong relationship between safety knowledge and riding confidence, showing that drivers can drive aggressively by feeling that individuals understand their skills and that aggressive behavior can be improved by increasing driver knowledge [11].

\subsection{Safety Attitude}

Safety Attitude is an attitude of personal responsibility in traffic safety and attitude towards traffic rules. Ulleberg et al. Sukor et al. found that perceived attitude and behavioral control were significantly related to motorcyclist safety [12];[13]. Wong et al. found that motorcyclists with different personality traits perceive risk differently, resulting in different risk behaviors [14]. Safety attitudes have a negative relationship with risky driving behavior, which means that relevant driving safety regulations and education are needed to prevent risky behavior [15].

\subsection{Riding Confidence}

Riding confidence is the main characteristic that contributes to the awareness of traffic conditions for friendly drivers [14]. On the other hand, the indirect effect of impatience on awareness of pure traffic conditions affects the perception of risk in driving. This shows that impatient drivers who are not aware of traffic conditions can cause them to worry about the surrounding conditions, which makes them nervous and easily distracts the driver's mind from being focused [14]. On the other hand, the dangers caused by impatience arise due to their lack of confidence and immature skills about traffic awareness and their response to risks in driving. In 
addition, the model results make it clear that driving confidence represents perceived behavioral control in the Theory of Planned Behavior model. This is in line with Tao Wang's research which states that driving confidence is not related to risky driving behavior, but is related to safety attitudes and risk perception [6].

\subsection{Risk Perception}

Risk perception is defined as an individual's subjective perception of the potential for harm. Yao and $\mathrm{Wu}$ say that risk perception is related to risky driving behavior, but it is still unclear what role riding confidence plays in risk perception [16]. Ulleberg and Rundmo said in their research that the perception of risk is significantly related to the attitude of drivers at risk [12]. Wang et al have verified that risk perception is the basis of safety driving attitudes [17]. Zheng's research provides a strategy by which personality characteristics can increase safety effectiveness and change their risk perception and safety attitudes and further reduce dangerous driving attitudes among drivers in China [18].

\subsection{Risky Driving Behavior}

Westerman and Haigney classify risky driving behavior as errors, violations, and deviations in driving [19]. Wang and Yin studied risky driving behavior in motorcyclists in Chongqing and produced types of risky driving behavior defined as reckless driving, speeding and trespassing, wrong driving, and reckless driving [20].

\section{MATERIALS AND METHODS}

\subsection{Research Sample}

The target population in this study were online motorcycle taxi drivers who had participated in the PT. Sarana Aman Berkendara and those who have not followed the driving safety program. The sample used is a sample that represents all elements in the proportional population. In addition, the data obtained will be processed using the SEM method.

\subsection{Instrument and Measurement}

There are 76 questions used in this study. We collect data by distributing questionnaires directly to online motorcycle taxi drivers. For the scoring mechanism, we used the Likert scale method. The Likert scale was chosen because it serves to measure the level of approval or disapproval of consumers/respondents as a reaction to questions posed through a questionnaire. In this study, 5 levels of the Likert scale will be used, namely ( $1=$ Strongly Disagree), (2 = Disagree), ( 3 = Moderately Agree), (4 = Agree), and (5 = Strongly Agree) .

\subsection{Data Analysis Tools}

The study uses the Partial Least Square (PLS) method through SmartPLS 3.0 software for processing the data obtained from the questionnaire. After knowing the relationship between variables explained in a literature review. We aim to build a conceptual model by combining 3 previous models, namely models generated by Tao Wang whose research model focuses on the effect of Safety Attitudes, Risk Perception, and Riding Confidence on Risky Driving Behaviors [6]. Chen Wang whose research model focuses on the problem of the influence of Safety Knowledge on Risky Driver Behaviors [17]. Lixin Jiang's research focuses on the problem of the effect of transformational and passive leadership on safety knowledge [21]. The following Figure 1 is a model of this research:

H1a: Safety Knowledge significantly gives a positive impact on Risky Driving Behavior

H1b: Safety Knowledge significantly gives a positive impact on Safety Attitude

H1c: Safety Knowledge significantly gives a positive impact on Riding Confidence

H2a: Safety Attitude significantly gives a negative impact on Risk Driving Behavior

H3a: Risk Perception significantly gives a negative impact on Risky Driving Behavior

H3b: Risk Perception significantly gives a positive impact on Safety Attitude

H4a: Transformational leadership significantly gives a positive impact on Safety Knowledge

H4b: Passive leadership significantly gives a negative impact on Safety Knowledge

H5a: Riding Confidence significantly gives a positive impact on Safety Attitude

H5b: Riding Confidence significantly gives a positive impact on Risk Perception

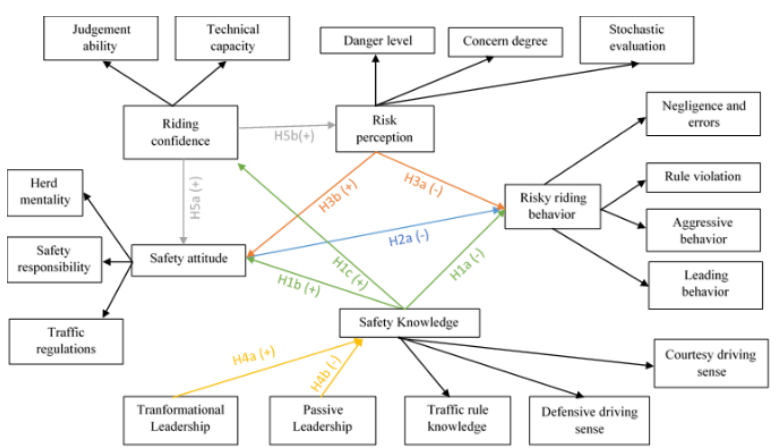

Figure 1 The Conceptual Model Result. 


\section{RESULTS}

\subsection{Characteristic of Respondent}

Based on the results, it is known that the number of respondents for drivers who participated in the safety program at PT. Sarana Aman Berkendara were 70 and 70 who have not participated in the driving safety program. Then for respondents who participated in the safety program at PT. Sarana Aman Berkendara was dominated by two age categories, namely $26-35$ years $(47.14 \%)$ and $35-45$ years $(32.86 \%)$. respondents who did not participate in the safety program were dominated by three age categories, namely $18-25$ years $(28.57 \%)$, 26-35 years $(34.29 \%)$, and $35-45$ years (27.14). Furthermore, for education, drivers who participated in the safety program at PT. Sarana Aman Berkendara the majority of respondents who graduated from senior high school education were 69 riders and 61 riders who have not participated in the driving safety program. After that in the experience category, respondents who participated in the safety program were dominated by 3 categories, namely 3 (37.14\%), 4 (27.14\%), up to 5 years $(31.43 \%)$, and who have not participated in the driving safety program are dominated by 3 categories, namely 1 (18.57\%), 2 (25.71\%), up to 3 years $(27.14 \%)$.

\subsection{Hypothesis Test}

The significance level used in this study was $95 \%$ $(\alpha=0.05)$ with the t-table of 1.96 . If the $t$-values of T-statistic $(|\mathrm{O} / \mathrm{STDEV}|)$ is less than 1.96, the hypothesis is rejected and the original sample shows the direction of the relationship as hypothesized in Figure 1.

\subsection{Riders participating in the program}

Based on the hypothesis testing result in Table 1. The original sample and the $t$ value were obtained in hypothesis. H1b and $\mathrm{H} 1 \mathrm{c}$ are $(0.180,1.062)$ and ($0.074,0.568)$. In this case, $\mathrm{H} 1 \mathrm{~b}$ and $\mathrm{H} 2 \mathrm{c}$ Rejected because the t-value is below the critical limit. On the other $\mathrm{H} 1 \mathrm{a}$ is accepted with the value of the original sample and the t-value $(-0.170,2.110)$ accepted. Other hypotheses, namely $\mathrm{H} 2 \mathrm{a}, \mathrm{H} 3 \mathrm{a}, \mathrm{H} 3 \mathrm{~b}, \mathrm{H} 4 \mathrm{a}$ are accepted because they have t-values of 3.929, 3.635, 5.052 , and 4.36 with the original samples being $0.408,0.403,0.452$, and 0.423 . Furthermore, H4b was rejected because the t-value is below the critical limit $(-0.066,0.742)$. Besides that, H5a is accepted with the value of the original sample and t-value $(0.232,2.007)$, while $\mathrm{H} 5 \mathrm{~b}$ is rejected because the $\mathrm{t}-$ value is below the critical limit $(-0.008,0.040)$.
Table 1. Hypothesis Test

\begin{tabular}{|c|c|c|c|c|}
\hline $\begin{array}{c}\text { Hypo- } \\
\text { thesis }\end{array}$ & $\begin{array}{c}\text { Original } \\
(\mathrm{O})\end{array}$ & $\begin{array}{c}\text { T Statistics } \\
(|\mathrm{O} / \mathrm{STDEV}|)\end{array}$ & $\begin{array}{c}\text { Original } \\
\text { Sample } \\
(\mathrm{O})\end{array}$ & $\begin{array}{c}\text { T Statistics } \\
(|\mathrm{O} / \mathrm{STDEV}|)\end{array}$ \\
\hline H1a & -0.170 & 2.110 & -0.363 & 2.313 \\
\hline H1b & -0.074 & 0.568 & 0.433 & 2.688 \\
\hline H1c & 0.180 & 1.062 & 0.163 & 1.326 \\
\hline H2a & 0.408 & 3.929 & 0.145 & 0.704 \\
\hline H3a & 0.403 & 3.635 & 0.216 & 1.090 \\
\hline H3b & 0.452 & 5.052 & 0.295 & 2.175 \\
\hline H4a & 0.423 & 4.365 & 0.361 & 3.906 \\
\hline H4b & -0.066 & 0.742 & 0.355 & 3.733 \\
\hline H5a & 0.232 & 2.007 & 0.170 & 1.359 \\
\hline H5b & -0.008 & 0.040 & 0.663 & 7.611 \\
\hline
\end{tabular}

\subsection{Riders who have not joined the program}

Based on the hypothesis testing result in Table 1. The original sample and the t-values obtained in the hypotheses $\mathrm{H} 1 \mathrm{a}$ and $\mathrm{H} 1 \mathrm{~b}$ are $(-0.363,2.313)$ and (0.433 2.688). In this case $\mathrm{H} 1 \mathrm{a}$ and $\mathrm{H} 1 \mathrm{c}$ are accepted. On the other hand, $\mathrm{H} 1 \mathrm{c}$ and $\mathrm{H} 2 \mathrm{a}$ are rejected due to the value is $(0.163,1.326),(0.145,0.704)$, it is rejected because the $\mathrm{t}$-value is below the critical limit. Other hypotheses, namely $\mathrm{H} 3 \mathrm{~b}, \mathrm{H} 4 \mathrm{a}, \mathrm{H} 4 \mathrm{~b}$, $\mathrm{H} 5 \mathrm{~b}$ are accepted because they have t-values of $2.175,3.906,3.733,7.611$ with original samples of $0.295,0.361,0.355$, and 0.663 . Furthermore, H3a and $\mathrm{H} 5 \mathrm{a}$ were rejected because the t-value is below the critical limits $(0.216,1.090)$ and $(0.170,1.359)$.

\section{CONCLUSION}

The first factor that influences unsafe driving behavior, according to study, is the sort of leader. According to the findings, transformational leaders can boost knowledge, whereas passive leaders who lack initiative can decrease driver safety knowledge. If described, these results indicate that drivers with the type of leader who provides examples of commitment will encourage and increase the safety knowledge of online motorcycle taxi drivers. Furthermore, there is the issue of safety knowledge, which might reduce unsafe driving behavior by boosting understanding. According to this result, drivers will have higher safety awareness and avoid unsafe driving behavior if they follow a driving safety program. Furthermore, according to the driving confidence factor and the results, drivers who complete the driving safety program have more self-confidence and can enhance their driving attitude. But when driving confidently without being 
balanced with driving safety knowledge, it will harm drivers who take risky actions. Furthermore, Risk Perception, the results of the study stated that the driver by following the safety program made the driver understand the dangers that might occur if he carried out risky driving behavior, so the driver chose to prioritize safety in driving. Next is the safety attitude factor. The results of the study show that safety attitudes affect reducing risky driving behavior, where drivers who follow the driver safety program understand the attitude of personal responsibility in traffic safety and attitudes towards traffic rules so that they can reduce risky actions.

The safety driving program at PT Sarana Aman Berkendara can reduce risky driving behavior. Still, it needs continuous and gradual support by conducting a safety campaign program about the dangers of risky driving, such as speeding, the presence of speed measuring cameras, cell phone interference while driving, and driving manners. It aims to reduce risky driving behavior. Strict enforcement of rules for motorcyclists also needs to reduce traffic accidents, such as licensing penalty points for traffic violators. The implementation of the safety campaign program can be used in the online motorcycle taxi driver application. Within a certain period, the driver must watch the safety education campaign video, and rewards can be given to riders who have finished watching until the video is finished.

\section{ACKNOWLEDGMENTS}

As the authors, we would like to thank all those individuals who have helped us in this research, so this research can be carried out properly and completed on time.

\section{REFERENCES}

[1] Papacostas, "Fundamentals of transportation Engineering," Pract. Hall, 1987.

[2] Astutik, "21,7 Juta Masyarakat Indonesia Pakai Transportasi

Online," www.cnbcindonesia.com, 2020. https:www.cnbcindonesia.com/tech/20200317 150135-37-145529/217-juta-masyarakatindonesia-pakai-transportasi-online (accessed Sep. 16, 2021).

[3] Kompas.com, "Demi keselamatan, Menhub meminta ojek 'Online' Kurangi kecepatan," www.kompas.com, 2019. https://otomotif.kompas.com/read/2019/01/07/ 072200415/demi-keselamatan-menhub-minta- ojek-online-kurangi-kecepatan (accessed Sep. $16,2021)$.

[4] R. Gozali, "Dilantas Polda Jateng Cermati Fenomena Kecelakaan dan Pelanggaran yang Melibatkan Ojol,” 2020.

[5] S. Riyandi, "Hampir 50 persen pengguna transportasi online kecewa," www.merdeka.com, 2017. https://www.merdeka.com/uang/hampir-50persen-masyarakat-kecewa-pakai-transportasionline.html. (accessed Sep. 16, 2021).

[6] T. Wang, S. Xie, X. Ye, X. Yan, J. Chen, and W. Li, 'Analyzing e-bikers' risky riding behaviors, safety attitudes, risk perception, and riding confidence with the structural equation model," Int. J. Environ. Res. Public Health, vol. 17, no. 13, pp. 1-17, 2020, DOI: 10.3390/ijerph17134763.

[7] J. Barling, C. Loughlin, and E. K. Kelloway, "Development and test of a model linking safety-specific transformational leadership and occupational safety," J. Appl. Psychol., vol. 87, no. 3, pp. 488-496, 2002, DOI: 10.1037/00219010.87.3.488.

[8] \& A. B. J. Bass, B. M., "Transformational leadership: A response to critiques," CA Acad. Press, vol. Chemers, , pp. 49-80, 1993.

[9] J. J. Hater and B. M. Bass, "Superiors' Evaluations and Subordinates' Perceptions of Transformational and Transactional Leadership," J. Appl. Psychol., vol. 73, no. 4, pp. 695-702, 1988, DOI: 10.1037/00219010.73.4.695.

[10] G. Blattenberger, R. Fowles, and P. D. Loeb, "Determinants of motor vehicle crash fatalities using Bayesian model selection methods," Res. Transp. Econ., vol. 43, no. 1, pp. 112-122, 2013, DOI: 10.1016/j.retrec.2012.12.004.

[11] W. Vanlaar, H. Simpson, D. Mayhew, and R. Robertson, "Aggressive driving: A survey of attitudes, opinions and behaviors," J. Safety Res., vol. 39, no. 4, pp. 375-381, 2008, DOI: 10.1016/j.jsr.2008.05.005.

[12] P. Ulleberg and T. Rundmo, "Personality, attitudes and risk perception as predictors of risky driving behaviour among young drivers," Saf. Sci., vol. 41, no. 5, pp. 427-443, 2003, DOI: $10.1016 / \mathrm{S} 0925-7535(01) 00077-7$. 
[13] N. S. A. Sukor, A. K. M. Tarigan, and S. Fujii, "Analysis of correlations between psychological factors and self-reported behavior of motorcyclists in Malaysia, depending on self-reported usage of different types of motorcycle facility," Transp. Res. Part F Traffic Psychol. Behav., vol. 46, pp. 509523, 2017, DOI: 10.1016/j.trf.2016.09.032.

[14] J. T. Wong, Y. S. Chung, and S. H. Huang, "Determinants behind young motorcyclists' risky riding behavior," Accid. Anal. Prev., vol. 42, no. 1, pp. 275-281, 2010, DOI: 10.1016/j.aap.2009.08.004.

[15] Z. Wang, R. L. Neitzel, X. Xue, W. Zheng, and G. Jiang, "Awareness, riding behaviors, and legislative attitudes toward electric bikes among two types of road users: An investigation in Tianjin, a municipality in China," Traffic Inj. Prev., vol. 20, no. 1, pp. 7278 , 2019 ,

DOI: 10.1080/15389588.2018.1511898.

[16] L. Yao and C. Wu, "Traffic safety for electric bike riders in China," Transp. Res. Rec., no. 2314, pp. 49-56, 2012, DOI: 10.3141/2314-07.

[17] C. Wang, C. Xu, J. Xia, and Z. Qian, “The effects of safety knowledge and psychological factors on self-reported risky driving behaviors including group violations for e-bike riders in China," Transp. Res. Part F Traffic Psychol. Behav., vol. 56, pp. 344-353, 2018, DOI: 10.1016/j.trf.2018.05.004.

[18] C. Zheng, Y. Liu, G. Ma, P. Deng, and J. Zhang, "Research on relationship between risk perception and cycling crashes in electric cyclists," Adv. Mech. Eng., vol. 11, no. 5, pp. 1-9, 2019, DOI: 10.1177/1687814019851639.

[19] S. J. Westerman and D. Haigney, "Individual differences in driver stress, error and violation," Pers. Individ. Dif., vol. 29, no. 5, pp. 981-998, 2000, DOI: 10.1016/S0191-8869(99)00249-4.

[20] Z. Y. Li, Y. Z., Wang, Z. G., \& Yin, "The relationship of road accidents with motorcyclists' riding behaviors, personality and attitudes towards safety," Psychol. Sci., vol. 2, pp. 491-493, 2008.

[21] L. Jiang and T. M. Probst, "Transformational and passive leadership as cross-level moderators of the relationships between safety knowledge, safety motivation, and safety participation,” J.Safety Res., vol. 57, pp. 27-32, 2016, DOI: 10.1016/j.jsr.2016.03.002. 